\title{
Introduction: New Perspectives on Secularisation in Britain (and Beyond)1
}

\begin{abstract}
This article reviews the recent developments in the debate on secularisation to establish the context within which the articles in this collection are located. It argues that the debate is complex and multi-faceted, and has been subject to refocus and redefinition in the last decade. The article traces the contributors' previous interventions in the debate, and summarises the articles in this volume. It concludes that the theme of secularisation remains of continuing interest to scholars precisely because it has such broad collections between history and other disciplines. Moreover the secularisation debate continues to engage scholars on different sides of the enlightenment divide.
\end{abstract}

The public discourse on secularisation has become both noisy and untidy. Issues of definition beset the topic: are terms like secularisation, desacralisation, rationalisation, disenchantment, modernisation and enlightenment synonymous? Or are there subtle but important differences between such terms? Are they processes or conditions and likewise do these have important and measurable consequences, causes or effects? Similarly, are terms like transcendence, immanence, spirituality, enchantment, sacred, belief and faith comparable, or to be contrasted and distinguished? Do these terms mean the same to historians, sociologists, philosophers, theologians, literary scholars and critics? Indeed the process of scholarly engagement with secularisation and secularisation theory has sometimes obscured rather than clarified the nature of both the debate and the contributions to it. This is, in part, a consequence of the wide-ranging exploration of the idea of secularisation. Its origins in sociology of religion and historical theology have spread further afield than its theoreticians might have expected. Among the recent contributions to the debate are ideas that both belief and secularisation had an impact on the politics of the Cold War and the ethics of nuclear armament.2 It has also been applied in non-Western societies, far distant from its intellectual origins.3 Secularisation

\footnotetext{
1 This Special Issue had its origins in the Ecclesiastical History Colloquium at Oxford Brookes University in January 2013 at which Callum Brown, David Nash and Jonathan Clark spoke. We are especially grateful that John Wolffe and Stefan Fisher-Høyrem, who also attended the Colloquium, and Dominic Erdozain have kindly agreed to contribute to the Issue.

2 J. Gorry, Cold War Christians and the Spectre of Nuclear Deterrence, 1945-1959 (Basingstoke: Palgrave Macmillan), 2015. J. Haynes, Religious Transnational Actors and Soft Power (Farnham: Ashgate, 2012). 3 V. Indira Devi, Secularisation of Indian Mind: A Study of Political Ideas in India from 1885 to 1914 (Jaipur: Rawat, 2002); Sang Tack Lee, Religion and Social Formation in Korea: Minjung and Millenarianism (New
} 
has also appeared in new discussions of urbanisation and the utilisation of public space.4 It has also developed an offshoot in contemporary discussions about the nature and future of education.5

Moreover those engaging in the debate find their views are influenced by the emergence of such ideas from the miasma of the discussion. Even in literary scholarship the issue of secularisation seems to be one capable of amendment and revision: in July 2015 Jeremy Gregory wrote that 'a distinguished and leading literature specialist, who as recently as 2005 had accepted the traditional secularising narrative of the period, now wants to put religion centre-stage as a key context and shaper of the literature and culture of the age.' 6

To add to this complex picture, proponents of secularisation themselves refine and revise their ideas in the light of the debates so that it sometimes appears to lack a wholly stable definition. Stephen Chavura and Ian Tregenza have pointed out that there is a paradox in the fact that, as terms like 'secular' and 'secularisation' are more widely used in society and in academic literature, their definition by theorists has narrowed.7 But in some cases the definitions, though narrowed, have become imprecise. John Milbank's 2006 work, Theology and Social Theory: Beyond Secular Reason has emphasised that secularisation can be regarded as a positive endorsement of humanism and human autonomy.8 David Martin, contrasting Europe and Latin America, argues that secularisation is not simply the absence of belief or the necessary result of social modernisation. Instead he sees it as driven by historical and cultural contexts and by theology and institutional structures. While he argues that religious and non-religious institutions have become increasingly differentiated over time, he does not see secularisation and modernity in quite the same relationship as earlier proponents of the theory. So religious ideas remain relevant and important in various societies but Martin suggests their general displacement from a traditional role in societies is one that can be

\footnotetext{
York: Mouton de Gruyter, 1996). S. Chavura and I. Tregenza (eds), Rethinking Secularism in Australia (and Beyond), Special Issue of the Journal of Religious History, 38/3, (2014).

4 H. Cox, The Secular City: Secularization and Urbanization in Theological Perspective (Princeton: Princeton University Press, 2013).

5 W. Alberts, Integrative Religious Education in Europe: A Study-of-Religions Approach (Berlin: de Gruyter, 2007). L. Franken \& P. Loobuyck (eds), Religious Education in a Plural, Secularised Society. A Paradigm Shift (Munster: Waxmann, 2011).

$6 \mathrm{~J}$. Gregory review of H. Weinbrot's Literature, Religion and the Evolution of Culture, 1660-1760 in The Journal of Ecclesiastical History, 66/3 (2015), 665.

7 S. Chavura and I. Tregenza 'Introduction: Rethinking Secularism in Australia (and Beyond)' in Journal of Religious History Special Issue, 38/3, (2014), 299.

8 J. Milbank, Theology and Social Theory: Beyond Secular Reason (Oxford: Blackwell, 2006).
} 
thought of as secularisation.9 Both Milbank and Martin's reformulated definitions have an indistinct and generalised quality that enables, rather than reduces, multiple interpretations.

Charles Taylor's restatement of secularisation in 2007 presented a much more complex picture than classical secularisation theory. On the one hand he argues for secularisation's 'hegemony of the mainstream master narrative' but rejects 'subtraction stories' in which history seems to be a process in which people gradually cast off the shackles of religious control and superstition. Moreover Taylor's chronology is much less clear than those of earlier theorists; the Renaissance, the Reformation, the Enlightenment and scientific revolutions all play their parts but not in a linear causal relationship to secularisation. They may have enabled men and women to shed the 'immanent frame' but Taylor does not claim any direct causal relationship. He places much more emphasis on ideas than events, so that the 'nova effect' of growing humanism separated people from any connection with the supernatural or a transcendent power. Taylor places considerable influence on movements such as Deism in the eighteenth century, which seemed to point to both individualism in religion and religious differentiation, and which placed Christianity almost beyond definition. Yet paradoxically Taylor argues that secularisation has left a gap in people's lives that has to be filled. And filled it can be, he says, by art, music, poetry and other transcendent forms.10

Steve Bruce's upbeat re-statement of secularisation theory in 2011 asserts that secularisation is a consequence of subtle but powerful features of modernization. Using a tidal analogy, religious experiences may ebb and flow, but faith is essentially retreating because each generation fails to transmit it to the next. Individualism and the erosion of the plausibility of religion mean that faith cannot withstand the inexorable march of the modern world. Bruce even contests the often-cited claim of American exceptionalism; he argues that while European and American secularising processes may be different there is no doubt that America is also experiencing the spread of modernity. But even Bruce accepts that some of the problems for secularisation as a theory have been caused by its diffusion and misuse by scholars. Secularisation theory stands in the dock and is impeachable because its proponents have been too loose in using it as universal solvent for many historical and social trends. 11

Scholars have also developed a sense of the dense complexity of the secularisation debate, most notably in Ira Katznelson and Gareth Steadman Jones's collection of essays Religion and the Political Imagination, which challenges classical secularisation theory and

\footnotetext{
9 D. Martin, On Secularization. Towards a Revised General Theory (Aldershot: Ashgate, 2005).

${ }_{10}$ C Taylor, A Secular Age (Cambridge, MA: Belknap Press, 2007).

11 S. Bruce, Secularisation: In Defence of an Unfashionable Theory (Oxford: Oxford University Press, 2011).
} 
places it under the microscope, questioning whether it is an inexorable process and whether it can be defined in the way scholars have previously done.12 Katznelson and Steadman Jones have also suggested the idea of 'multiple secularities'.13 Their view of contemporary secularisation is informed by historic treatments of the separation between politics and religion, such treatments they suggest should become more differentiated. All of these views seem to be distant from Weber's interpretation of secularisation.

Clearly the secularisation debate is one which shows no sign of abating. Rather in the same way that some scholars suggested a decade or more ago that the controversy over the optimistic or pessimistic view of the eighteenth century Church of England had runs its course, so those who think there cannot be more to be said on secularisation must be perennially disappointed. The contributors to this special issue of the Journal of Religious History have also made significant interventions in the debate on secularisation. Callum Brown's body of work has formed a distinguished contribution to the discussion of the perceived decline of religion in Britain since the 1960s and has been especially significant in addressing issues of gender.14 David Nash's work on secularisation is a product of his work on Secularism and blasphemy in both Anglo-American and European history and of the wider narrative nature of Christian history.15 John Wolffe's work on secularisation is rooted in his examination of the role of religion in public life. His studies of evangelicalism in Britain and across the world have informed his understanding of Christianity's 'loss of monopoly' in Britain.16 Dominic Erdozain's analysis of secularisation is located in his

12 I. Katznelson and G. Steadman Jones, Religion and the Political Imagination (Cambridge: Cambridge University Press, 2010).

13 An idea also endorsed in M. Warner, J. Vanantwerpen \& C. Calhoun (eds), Varieties of Secularism in a Secular Age (Cambridge, MA: Harvard University Press, 2012).

14 C. G. Brown, The Death of Christian Britain: Understanding Secularisation 1800-2000 (Routledge: London, 2001 revised 2009); Religion and the Demographic Revolution: Women and Secularisation in Canada, Ireland, UK and USA Since the 1960s (Woodbridge: Boydell Press, 2012); 'Men losing faith: the making of modern no religionism in the UK 1939-2010' in L. Delap and S. Morgan, (eds.) Men, Masculinities and Religious Change in Twentieth-century Britain (Basingstoke: Palgrave Macmillan, 2013); 'Gender, Christianity and the rise of no religion: the heritage of the sixties in Britain', in N. Christie and M. Gauvreau (eds.) The Sixties and Beyond: Dechristianization in North America and Western Europe, 1945-2000 (Toronto: University of Toronto Press, 2013); 'Unfettering religion: women and the family chain in the late twentieth century' in J. Doran, C. Methuen, and A. Walsham (eds.) Religion and the Household. Studies in Church History, 50 (2014).

15 D. S. Nash, Secularism, Art and Freedom (London: Leicester University Press, 1992); Blasphemy in Modern Britain 1789-present (Aldershot: Ashgate Publishing, 1999); Blasphemy in the Christian World (Oxford: Oxford University Press, 2007); Christian Ideas in British Society: Stories of Belief in the Twentieth Century (Basingstoke: Palgrave Macmillan, 2013).

16 J. R. Wolffe, God and Greater Britain: Religion and National Life in Britain and Ireland 1843-1945 (London: Routledge, 1994); The expansion of evangelicalism: The age of Wilberforce, More, Chalmers and Finney (Nottingham: Intervarsity Press, 2006); A Short History of Global Evangelicalism (with Mark Hutchinson) (Cambridge: Cambridge University Press, 2012); 'Christianity: loss of monopoly' (with M. Guest and E. Olsen) in L. Woodhead, and R. Catto, (eds.) Religion and Change in Modern Britain (London: Routledge, 2012), 57-78. 
historical interests in pleasure and pain. Nevertheless his preoccupation with the Victorian period is much extended in a foreshadowing of his latest work on doubt from Luther to Marx.17 Stefan Fisher-Høyrem's work on secularisation directly addresses Charles Taylor's work.18 Given the diverse perspectives of the contributors, this is not a collection of essays that speaks with a single voice and directly connects with each other. Indeed given the specialist interests of the contributors, their articles demonstrate the breadth of responses to the secularisation debate from historians rooted in intellectual history, religious history, the history of modern evangelicalism and the social and cultural history of the nineteenth century.

Callum Brown's essay brings atheism into the centre of the debate on secularisation. He defines an atheist as one who doesn't identify with religion, undertake religious practice or believe in God. Brown takes Charles Taylor's A Secular Age as the basis on which to examine atheism. Taylor, in Brown's account, establishes a bi-polarity in Western history, in which the idea of atheism in the medieval period was impossible and from 1950 when secularisation did not mean the rise of atheism but the decline and transformation of religion. Paradoxically, argues Brown, Taylor neglects atheism. In doing so, Taylor ignores the evidence of medieval scepticism, doubt and even hostility to religion. Brown argues that much modern scholarship has demonstrated that the medieval era was one in which unbelief was present and significant. In looking at the process of secularisation, Taylor argues for disenchantment -a move from uniformity to diversity of belief rooted in rational humanism. This for Brown represents a degradation of religion (and in particular Christianity), stripping away supernaturalism and superstition. But importantly neither of Taylor's poles engages with atheism. For Brown, atheism is typified by a spectrum of views, in which life is lived as if God does not exist -though without specific activity, which overlaps with belief and which has a distinctive moral outlook. Brown gives us three case studies to illustrate these characteristics. What such examinations of atheism suggest is that the measurement and definition of secularisation from the premise of religion "warps the possibility of envisioning

17 D. Erdozain, 'The Secularisation of Sin in the Nineteenth Century' in Journal of Ecclesiastical History, 62/1 (2011), 59-88; The Problem of Pleasure: Sport, Recreation and the Crisis of Victorian Religion (Woodbridge: Boydell Press, 2010); 'Christianity and social service in modern Britain: the disinherited spirit' in The Historical Journal, 52/2 (2009), 535-536; Erdozain's forthcoming book promises to view secularisation in a much longer timescale: The Soul of Doubt The Religious Roots of Unbelief from Luther to Marx (Oxford: Oxford University Press, 2015).

18 S. Fisher-Høyrem, 'Charles Taylor and Political Religion: Overlapping Concerns and Points of Tension', Religion Compass, 7 No 8, (2013), 326-337. 
secularity in anything like its true light.' Indeed for Brown any examination of secularisation has to include atheism.

Stefan Fisher-Høyrem's analysis engages with the secularisation thesis by deploying Taylor's concepts of 'the social imaginary' and of the 'secular' as a form of time. FisherHøyrem identifies the Victorian era as one in which the ancien regime imaginary gave way to a mobilisation 'social imaginary' characterised by a collective consciousness and the technological character of the period. By 'mobilisation imaginary' Taylor and Fisher-Høyrem suggest one in which the social structures people seek to engage with have to be 'mobilised' into existence. Fisher-Høyrem also argues that intrinsic to secularisation is a shift in the nature of time and time-consciousness. He argues that, in the medieval period, time was complex, operating in temporal but also spiritual and eternal spheres. However by the end of the eighteenth century this multiple time consciousness changed. It shifted from a multiple time consciousness to a simple linear one, and this transformation was one of the features that characterised the Victorian age. Fisher-Høyrem's argument is illustrated by reference to newspapers. Newspapers gradually brought the time horizon much closer to the linear temporal experience, in doing so they utilised technological advances such as telegraph and new printing techniques. While newspapers and society as a whole continued with a preoccupation with religious issues, they did so in transformed time frames and with a mobilisation imaginary, which can be described as 'secular'. Thus the Victorian public sphere was predicated on a secular concept of time and framed by a constructed imaginary which may have included religion but did not mandate belief. In this way Fisher-Høyrem argues that we can reconceive the Victorian period as one which was secular.

Dominic Erdozain analyses secularisation from the viewpoint of enlightened thinkers such as Spinoza, Voltaire and Feuerbach, seeing each of them operating in the shadow of an Augustinian model of Christianity. Erdozain sees the roots of unbelief in two competing Christian theologies: Augustine's theology of faith and judgement and theologies of love and compassion. Tracing the origins of scepticism of a god of retribution and punishment to Castellio's attack on Calvin's role in the execution of Michael Servetus in 1553, Erdozain asserts that this rejection of religious violence was shared by later thinkers. He recovers Spinoza not as an Enlightenment atheist but as a believer in a god of love, presenting true Christianity as life-sustaining not forbidding and punitive. Spinoza rejected attempts by church authorities to claim authority over mankind as fraudulent and simply wrapping human urges in a divine cloak. Equally, Erdozain sees Voltaire as committed to a god of love and rejecting the censorious and persecuting instincts of the Jansenists which sought to exclude 
some from the divine. In this formulation Voltaire is not an agent of Enlightenment scepticism but of tolerant and compassionate Christianity against Augustinianism. Ironically Voltaire regarded the absolutist tendencies of Holbach's atheism as of the same substance as Augustinian 'misanthropic' theology. The same tension between Augustinianism and tolerant Christianity can be seen in the Victorian crisis of faith, evident before Darwin. Francis Newman, James Anthony Froude and others shuddered at the 'prison house' orthodox theology which emphasised punishment for transgression without a thought to divine love. For Erdozain, the high point of this conflict between Augustinian and liberal theology is in Ludwig Feuerbach turn to atheism. Feuerbach's abandonment of the church lay in his view that Christianity, at least that advanced by Augustine, endorsed human selfishness and that god had become simply a grand justification of human vice. Augustine's insistence on faith and the consequences of violence and retribution for those who cannot always sustain it was, for Feuerbach, immoral and impossible. Like Voltaire, Feuerbach saw much more in common between religious vengeance and atheism and like the Victorians he saw hell as the invention of a severe unyielding faith not of a compassionate god. So for Erdozain secularisation is not a process of unbelief assaulting belief but of different views of god locked in a duel.

David Nash's critique of secularisation is rooted in the relatively renewed scholarly interest in the idea of historical narrative, and its power. Nash views the unfashionable nature of meta-narratives as a source of the adoption of secularisation theory, but emphasises that secularisation itself has become such a narrative with all of the inherent problems of flagging explanatory power. If secularisation has become, in his terms, 'a belief system', it is incumbent on religious historians to treat it in the same way as they would a religious faith and subject it to the same types of analysis. The narrative analytical approach, Nash argues, enables historians to describe individual experiences within faith and also within secularisation. Three such locations of narratives which Nash explores are urbanisation, feminization and the place of universities. These three, so Nash claims, are able to be deployed by proponents and opponents of secularisation theory in defence of their positions. Narratives like these also lend themselves to explorations of 'moments' in the development of belief and unbelief. Those moments can be gradual turning points, such as Edward Norman and Simon Green identified in their work, or they can be cataclysmic instants which Callum Brown's Death of Christian Britain suggested. Secularisation theorists have adopted both evolutionary narratives and occasions of cataclysm in advance of their model. 
A fundamental ingredient in Nash's view is the commitment of secularisation theorists to a narrative of the past which replicates that of traditional religious historians and some religious practitioners. Despite its 'subtraction' element, secularisation theory is essentially teleological and positivist, with alternative humanist salvation and redemption in the form of self-actualisation and humanistic self-sufficiency. But these ideals within such narrative structures are as prone to disenchantment and re-enchantment as faith in the narratives of the Abrahamic God. In this way, secularisation theorists like Charles Taylor have simply developed narratives of a new form of 'belief' rather than a refutation of such beliefs. Like the Marxist meta-narrative, secularisation theorists have created new fables and myths which too readily fail to advance a cogent explanation of social change. Consequently, Nash's solution is not to treat secularisation as a postmodern phenomenon which demolishes narratives of faith, but to claim it as another such narrative, some of whose claims are reasonable and others are not. In this way, Christianity, Islam and secularisation are encountered and engaged with in ways that have more in common than perhaps hitherto realised.

John Wolffe's study of secularisation in London in the last century rests securely on data analysis. He challenges the assumption that urbanisation, or the urban environment, was inevitably hostile to religion and also that the middle classes were the most sympathetic to organised religion. Drilling into the data, Wolffe shows the complexity of some of the trends which have often been the bedrock of secularisation theory among both sociologists and historians. In particular he demonstrates that religious decline and resurgence were not sequential historical processes. Thus in the 1990s there was both a decline in Anglican church attendance and evidence of a rise in membership and in numbers of church buildings. Outside the Church of England the period also witnessed decline in Roman Catholic and Methodist attendances but a rise in those of the Baptist Church. The complexity of the evidence is also evident in the case of migration, which is often assumed to have been the main source of the growth of Pentecostalism. In fact the growth of Pentecostalism alone cannot be ascribed to inward migration since many immigrants were Muslin rather than Christian Pentecostals. Beyond Christianity, Wolffe shows that internal migration might well account for the decline in Jewish communities in London but a rise in those communities neighbouring London such as Hertfordshire. Among the Islamic, Hindu and Sikh communities growth was a feature of the period and one which had its roots in the decade usually assumed to have been the low point of faith, the 1960s. This sort of sophisticated and detailed data analysis is important in seeing more significant trends. Among these is that the balance between people who claimed 
in censuses to have 'no religion' shifted between 2001 and 2011, so that by the latter date London had a lower percentage of 'no religion' respondents than the rest of the United Kingdom.

In their introduction to the special issue of this journal in 2014, on 'Rethinking Secularism in Australia (and Beyond)', Stephen Chavura and Ian Tregenza suggested that there was a 'fundamental connection' between secularism and the Enlightenment.19 This thought led them to question whether 'post-Enlightenment' societies might still grapple with the issue of secularism and secularisation. In fact, of course, their collection of essays showed abundantly that debates on secularism, on Taylor's 'social imaginary', on secular narratives, and on minimalist religion (or what was termed 'Civic Protestantism') remain powerful and significant in Australia as much as in Europe or North America. Consequently the multiple meanings and definitions of secularisation demand continued analysis and examination. In some respects the issue of the Enlightenment, whether or not it is freighted with the universal determinism so often adopted by its proponents, is one which continues to frame the debate on secularisation. As a result in 'post-Enlightenment' and 'Enlightenment' societies the discourse on secularisation continues to be one of the most potent and significant of public debates.

${ }_{19}$ S. Chavura and I. Tregenza, 'Introduction: Rethinking Secularism in Australia (and Beyond)' in Journal of Religious History Special Issue, 38/3 (2014), 300. 